\title{
Innovation and Market-Driven Management in Fast Fashion Companies
}

\author{
Elisa Arrigo*
}

\begin{abstract}
In hyper-competitive markets, innovation is critical for the growth of marketdriven companies. An examination of case studies of highly competitive global companies in the fast fashion sector, reveals that detailed understanding of the market, deriving from direct management of their stores, enables Zara, Gap and $H \& M$ to develop an innovation management capability. This is a fundamental competitive driver for the company's success.
\end{abstract}

Keywords: Market-Driven Management; Innovation; Fast Fashion; Global Competition; Zara Case; Gap Case; H\&M Case

\section{Market-Driven Management and Information Management}

In recent years, many companies have embarked on development processes based on a competitive approach to the market, through: the creation of a corporate culture that addresses the outside world; a number of distinctive capabilities to understand the market and a structural configuration that effectively manages information flows (Brondoni, 2009; Day, 1994). A market-driven company is part of a system of corporate relations that provides better access to information about customers, competitors and the other players on the competitive scene (Narver, Slater, 1990; Kohli, Jaworski, 1990).

In major theoretical discussions of market-driven management, the management of information flows has always been of crucial importance. For example, Kohli and Jaworski (1990), define a market orientation as a company's ability to generate, disseminate and use better information about its customers and competitors. According to the authors, the key processes of this approach are: the implementation of market intelligence mechanisms and the continuous dissemination of the data acquired; their analysis and processing; and finally, adequate and anticipated satisfaction of the market's needs. Narver and Slater (1990) retain that, as well as orientation to demand and to competition, a market-

*Assistant Professor of Management, University of Milan-Bicocca (elisa.arrigo@ unimib.it) 
driven company has a degree of inter-functional coordination that can optimise the acquisition of information about customers and rival companies, and spread it to the entire organisation.

We can therefore state that a market orientation fosters the collection of indications and data regarding demand, the competition and environmental trends. However, this information can only act as a platform to generate future activities if the company develops a capacity for learning that simplifies the acquisition, interpretation and incorporation of the knowledge generated in company procedures (Baker, Sinkula, 1999). As a result, it is not simply a question of collecting a great deal of information, but of generating new knowledge through interaction with other players on the market.

Baker and Sinkula (2002) underline that a learning orientation derives from the presence of values in the corporate culture, that urge the company to proactively strive to acquire new knowledge, even at the cost of questioning the existing status quo. In fact, marketing information processing activities, which are crucial for strategic planning, are based on the company's degree of market orientation: the more a company focuses on studying its competitors and demand, the greater its predisposition to process a wealth of information.

Empirical evidence also shows that market-driven management and learning orientation are both positively correlated to the ability to undertake future innovation; in other words, in a strongly market-oriented company that is structured to generate new knowledge, a greater capacity for innovation is generated ${ }^{1}$ (Baker, Sinkula, 2002; 2009). In other words, for the market-oriented company, the creation of know-how and the improvement of learning processes represent both a reaction to the challenges posed by the dynamism and turbulence of global markets and a mechanism on which to base positive confrontation with the competitors.

\section{The Innovation Management Capability}

To compete successfully, the market-driven company learns faster from the market than its competitors and, to this end, it develops a series of skills and capabilities that allow it to coordinate the various company activities on a global scale.

$\square$ In relation to the continuous interchange with the environment, Day (1994) identifies three types of capabilities: outside-in capabilities (they tie corporate strategies to analysis and interpretation of the external environment and are activated by market requests, by competitive challenges and external opportunities); inside-out capabilities (regarding the company's internal production, logistics and HR management processes in order to grasp external opportunities); and spanning capabilities (necessary to combine inside-out and outside-in capabilities).

Market-driven companies pay particular attention to the development of outsidein capabilities, aiming to identify a core competence of their own (Prahalad, Hamel, 
1990), in other words a particular skill that distinguishes each company from its competitors. Because today's market evolves constantly, this capability must be dynamic (Teece, Pisano, Shuen, 1997) in order to monitor the changes to the operating contexts and to make the organisation flexible.

Market-driven companies are able to integrate, build and reconfigure internal and external skills to align and respond rapidly to environmental changes. In global markets, they control multiple competitive variables, in the knowledge that cost and quality factors are necessary drivers but not sufficient to acquire superiority over the competition. A company's strategic focus therefore shifts from striving for the lowest cost or control over quality in a segment to the capacity to innovate. In fact, improvements in manufacturing efficiency are often accompanied by refinements to quality and this is occasionally possible thanks to the competitive relations system that the company is a part of (Zucchella, 2004). The partnership networks that are often created between companies to reach shared goals make it possible to simultaneously achieve advantages both in terms of cost, through economies of scale and of scope, and in terms of differentiation. In hypercompetitive environments, innovation ${ }^{2}$ therefore becomes essential to maintain a position of market domination.

As an integral part of the strategies designed to generate competitive superiority, innovation may regard different aspects of corporate management, such as: organisational forms, logistic processes, IT, manufacturing outsourcing, etc.. This complicates the classification of the various types, in view of the vast spectrum of available options. For example, Hamel (1996) defines as innovative a rule-breaker company that is able to change the rules of the competitive game; for Abell (1978) a company is innovative when it is able to reconfigure the elements of its business system in an original way, forging itself a new market space (Strategic Windows).

A company's strategic propensity for innovation becomes evident from the moment it states its corporate mission: the vaster the definition of the business in which a firm intends to operate, the greater the possibilities for development in terms of future innovation.

$\square$ For example, the business concept of H\&M is: 'to give the customer unbeatable value by offering fashion and quality at the best price'. The business in question is fashion in its widest sense, not just limited to the clothing sector. The company opened its doors in the 1950s only selling clothing for men and women, whereas its stores now carry accessories, cosmetics and beauty products too.

In global companies operating in competitive markets, innovation processes may be the result of skills developed internally or triggered by requests from demand or by interaction with customers or partners who are involved in the definition of new products. In certain circumstances, innovation may be born from imitation of the competitors; in that case, the company does not develop a distinctive innovative capability internally, but successfully and rapidly reproduces an innovation that other companies have devised and launched on the market before it.

In hypercompetitive situations, the distinctive capabilities of market-driven companies must include an 'innovation management capability' because only 
through incessant innovation processes will they reach a good competitive position and acquire subsequent advantages over the competition. The expression 'innovation management capability' refers to a firm's efforts to control a competitive variable that is difficult to manage because of the many forms in which it is expressed as well as the high competitive pressure on today's markets. It is obvious that an aptitude to manage innovation effectively stems from a firm's ability to exploit the wealth of information at its disposal, generating learning (thanks to market information processing) and new knowledge.

The company exploits its innovation management capability to keep all the sources of innovation under control as well as those implemented by the competition in order to gasp new business opportunities. In fact, the competitive advantage acquired by a given company, in a given time and space, cannot be maintained in the long term in extremely dynamic competitive contexts. In other words, it is the company itself that 'breaks' the balance between competitors, developing innovation with continuous product advancements and the creation and abandon of demand 'vacuums' (marketbubble management) (Brondoni, 2009).

The time factor (time-based management) and the company's wealth of information play a key role in the management of its capability to control innovation. In fact, whether innovation is born out of a distinctive corporate capability or from imitation of the competitors, the innovative idea must be developed and managed in as short a time as possible. This reduces the interval between the creation of the innovation or the choice of the one to imitate, and the moment in which the company enters the market with an offer that has a higher perceived value than rival offers. For a market oriented company, controlling innovation from a strategic viewpoint means both continually monitoring the innovations adopted by the competitors and assessing the results in terms of value for the end customer ${ }^{3}$. What is more, the corporate information system will have the primary role of developing new knowledge of the market and managing manufacturing, logistic and financial flows so that strategic action can be taken by the established deadline. And because the dynamism of the markets and the fierce rivalry between companies demand rapid, effective action, the ability to manage innovation entails establishing sensors that recognise the signals indicating future trends and mechanisms that catalogue every fact or information that can influence corporate activity.

A competitive orientation therefore prompts firms to exercise influence on the market structure or on the behaviour of its players in order to improve their competitiveness. Companies go beyond mere observation of competitors and understanding of consumers' needs. Jaworski et al. (2000) and Tuominem et al. (2004) underline that market-oriented companies should remodel their manufacturing chain by eliminating and adding partners depending on the conditions on individual markets, or by assigning new roles to existing partners according to the company's needs ${ }^{4}$. These companies are therefore strongly innovative and possess a marked ability to manage innovation even inside its own supply chain.

The theoretical considerations set out so far are applied concretely in the fast fashion sector which is a particularly interesting field of application. First of all, it regards the clothing sector, which is oversupplied and highly competitive. It is also characterised by extensive strategic innovation and a focus on product distribution. 
The goal of this article is to analyse the various ways in which the most important fast fashion companies develop their innovation management capability by direct management of their sales network all over the world. In recent years, following the globalisation of the markets, many companies have embarked on plans to extend their activities (market-space management), creating mega-organisations with global networks that establish competitive relations that go beyond international organisations. (Brondoni, 2008).

To this end, the research project has analysed the case studies ${ }^{5}$ (Yin, 2003; Gummesson, 2000) of a number of large global companies with a strong competitive profile. The companies selected for analysis are the Spanish firm Zara (part of the Inditex Group), the Swedish firm Hennes \& Mauritz (H\&M), and the American firm Gap (of Gap Inc.) because they are the only ones that are integrated upstream, have a chain of single-brand stores, and operate globally. ${ }^{6}$ What is more, the companies selected invest significantly in innovation as we can see, on one hand, from the variety of the fashion products sold and, on the other, from the new management, distribution and communication methods that they have introduced. Analysis of the case studies and data collection are based both on secondary sources (literature reviews, corporate documents like annual reports, social and environmental reports, press releases and websites) and on interviews and conversations with managers and experts from the sector.

\section{Market-Driven Fast Fashion Firms}

The fashion sector can be broken down into: haute couture (very prestigious articles, accessible to a chosen few, often hand-made and tailor-made for special occasions), prêt-à-porter (deriving from the democratisation of haute couture, referred to articles that can be worn in every-day life), diffusion (the secondary lines of leading stylists, addressing a broader public), bridge (more accessible and functional creations) and finally, the mass market (firms specialised in selling fashion items at low cost to a very broad public) (Cillo, Verona, 2008).

This last mass-market group includes the fast fashion companies Zara, H\&M and Gap, which combine a focus on fashion with accessible prices. Their entry on the market has sustained consumption globally in the clothing sector in spite of the current economic crisis. By combining rapid processes with a short time to market and the creation of an original brand that is distinctive and immediately recognisable, these companies have filled important positions even in fashionrelated sectors. From their initial focus on men's, women's and children's clothing, they have since spread to underwear, beachwear, footwear and accessories (scarves, sunglasses, hats, belts, etc.).

H\&M, Zara and Gap often define themselves as fashion retailers to highlight their constant focus on the distribution side of their products; in fact, strong competition and saturated demand have underlined the need for all companies to control the distribution network, so as to be closer to the market and the end consumer. ${ }^{7}$ Many firms in this sector have adopted vertical integration strategies, demonstrating the importance of owning the sales network even if this means outsourcing all or part of manufacturing to external partners (Tokatli, 2008). 
A brief description of the fast fashion companies analysed follows.

$\square$ The Swedish chain H\&M (Hennes \& Mauritz AB), founded in Vasteras by Erling Persson in 1947, is listed on the Nasdaq OMX of Stockholm. In 2009 it recorded sales of approximately Swedish Krona 119 billion (about Euro 13.273 billion). It operates in 34 countries with approximately 76,000 employees, and its shops, which are supplied on a daily basis, sell: items of clothing (men, ladies, kids), cosmetics and accessories. The collections are created by a team of one hundred designers who work in close contact with the purchasing department and with the partners. H\&M does not manage the manufacturing activities directly, because it does not own any manufacturing plants, but is supplied by numerous independent suppliers. H\&M recently adopted a brand portfolio strategy, acquiring the COS-Collection of Style (23 stores), Monki (35 stores), WeekDay (10 stores) and Cheap Monday (one store) brands. H\&M has also entered the home products business with H\&M Home which has a single showroom in Stockholm. As we can see in Figure 1, illustrating the breakdown of H\&M sales by geographical macro area, $93.7 \%$ of sales are achieved outside the company's original home country (Sweden).

Fig. 1: H\&M Sales by Geographical Area (2009)

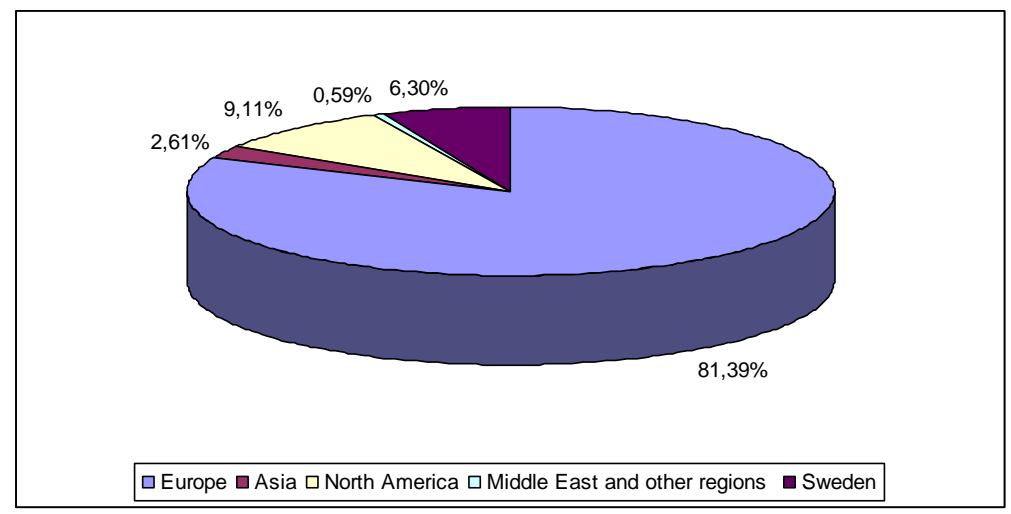

Source: Elaborated by the author using H\&M data (H\&M Annual Report 2009)

$\square$ Zara is one of the eight brands (Zara, Massimo Dutti, Pull and Bear, Oysho, Bershka, Stradivarius, Zara Home and Uterque) of the Spanish Inditex Group created by Amancio Ortega Gaona in 1985 and listed on the stock exchange since 2001. With 92,301 employees, the group registered sales of Euro 11,084 billion in 2009. Zara was founded in La Coruña in 1975 and now leads the group with sales of Euro 7,077 million in 2009, thus accounting for almost $64 \%$ of global Inditex sales. The first store outside the Spain was inaugurated in Portugal in 1988; since then growth has been very strong and today 
Zara is also present in countries that are culturally very distant from Spain, like Saudi Arabia, Japan, China and India. Unlike its main competitors, Zara produces part of its clothing directly, controlling its entire supply chain. This allows the company to rapidly vary the product assortment to respond to sales trends. The rest of production is outsourced to companies most of which are located in Europa and Asia. The creative team of two hundred people prepares the collections, supplying the designs and renderings to the external partners. As we can see from Figure 2, 68\% of Inditex sales are achieved outside Spain.

Fig. 2: Inditex Sales by Geographical Area (2009)

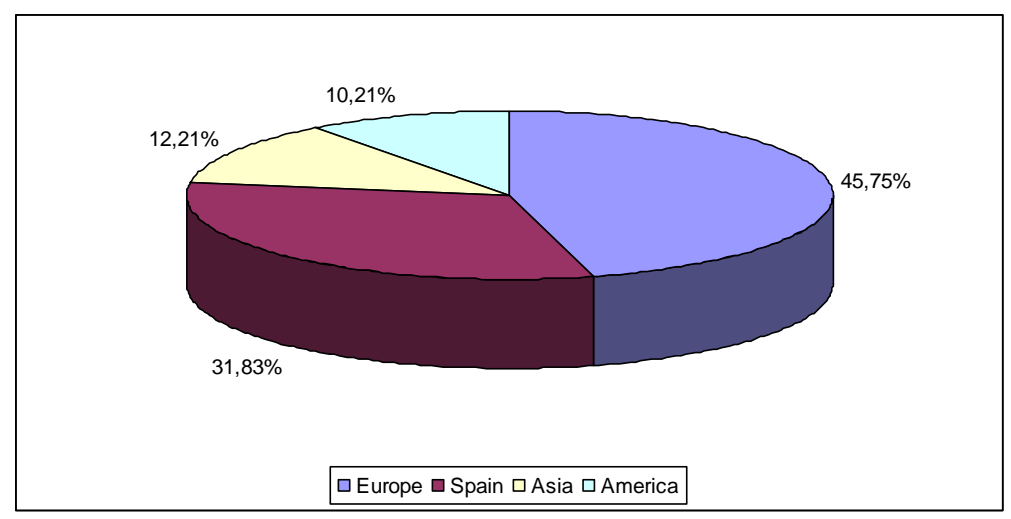

Source: Elaborated by the author using Inditex data (Inditex Annual Report 2009)

$\square$ Gap Inc. was founded in San Francisco in 1969 by Doris and Don Fisher, and is one of the largest specialty retailers, listed on the New York stock exchange. The group has approximately 134,000 employees and recorded sales of \$14.2 billion in 2009 (approximately Euro 10.627 billion). It owns the Gap, Old Navy, Piperlime, Athleta and Banana Republic brands through which it distributes personal care products, clothing and accessories for women, men and children. Gap, Banana Republic and Old Navy have stores whereas Piperlime and Athleta only sell online. The Gap brand was recently launched on a number of foreign markets (Asia, Indonesia, Malaysia, Singapore, South Korea, Israel, United Arab Emirates) and 34\% of sales are currently achieved outside the United States. The collections are designed in part by internal designers and in part purchased from external stylists. Manufacturing on the other hand is entirely outsourced and 99\% of the articles sold by Gap are made outside the United States. However, sales are primarily concentrated in the United States, with only $20 \%$ outside the country, as shown in Figure 3. 
Fig. 3: Gap Inc. Sales by Geographical Area (2009)

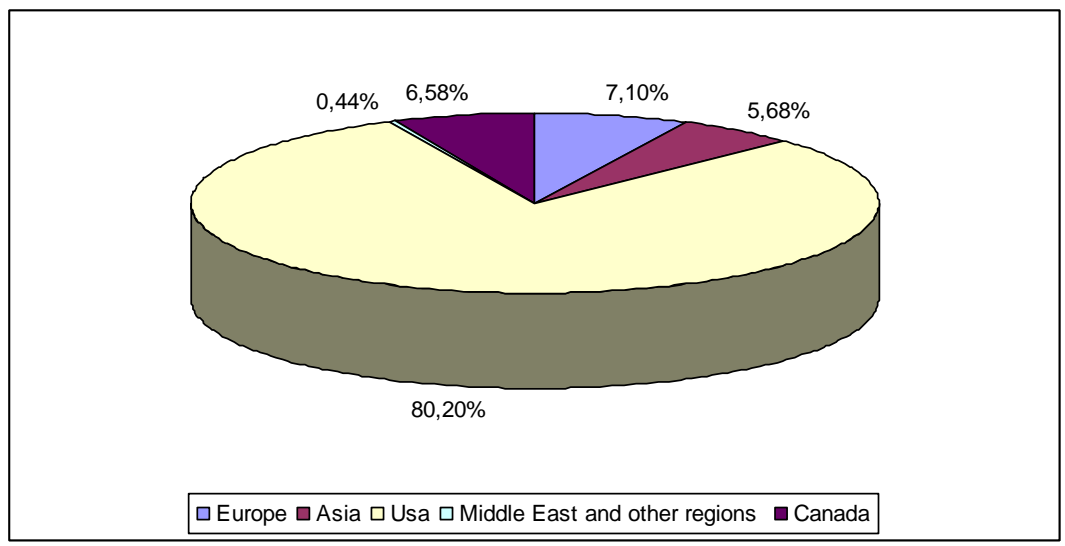

Source: Elaborated by the author using Gap Inc. data (Gap Inc. Annual Report 2009).

Numerous development factors of fast fashion firms are analysed in literature and they are often inter-related. The success of these companies on the global competitive scenario derives from their ability to control all these drivers simultaneously at a supranational level.

In the following paragraphs we intend to summarise the main elements for analysis of the fast fashion industry and to contribute to the study of these companies' global distribution structures, a factor which we believe may foster their ability to manage innovation.

The development factors of Gap, H\&M and Zara may be divided into three basic elements:

- management of the supply chain, focusing constantly on time management;

- information management and development of information and communications technology;

- store management and customer linking capabilities.

\subsection{Fast Fashion, Supply Chain and Time-Based Competition}

The speed of their processes is certainly an essential element of the Zara, H\&M and Gap strategies, but it is not the only one responsible for their success: the 'time' variable is an aspect of the management of the entire chain from the first stages of the choice of materials right down to the creation of numerous shops in all industrialised countries.

Time is critical for every firm in the fashion sector, because every item can rapidly go 'out of fashion'. Stylists traditionally start to plan their collections for the coming seasons up to eight months before their market launch, obviously running a high risk of failure due to the instability of demand and the short life cycle of clothing products. Companies in the fast fashion business do not need as much time to define their ranges, because they wait for the collections of the large fashion houses to be presented (at least one season in advance), they identify the prevailing trends and they design their items to reflect these trends. This allows them to offer a new range of items in just four to six weeks. Time-based 
competition logics cut the time for each stage of the manufacturing chain, from purchasing times through manufacturing to marketing, and the very short time between the design of the product and its market launch makes it possible to propose products that are always 'fashionable'.

$\square$ Zara takes only four to five weeks to design a new collection and then a week to make it. With its team of commercials sniffing out new fashions while keeping in constant contact with store managers, the company can spot and react to trends quickly, including taking something stylish off a music video. Other retailers, in contrast, need an average of six months to design a new collection and then another three months to manufacture it, according to Inditex Chief Executive Jose Maria Castellano. 'Fashion expires, much the same way yogurt does,' he says. 'Being so quick allows us to reduce to a minimum the risk of making a mistake - and we do make mistakes - with our collections.' (Vitzthum, 2001, p. B1)

The speed and the need to monitor all stages of production can also discourage the choice of locations that are too far away, even if they offer manufacturing costs well below those of the home country (Mihm, 2010). The decision to opt for a geographically close partner is also linked to the problem of transport costs which impact significantly on the final price of the product as a result of rising oil prices.

Sullivan and Kang (1999) call this approach 'quick response' based on just-intime manufacturing methods but referred to clothing companies. To achieve a short time to market and to reach the market before the competition, companies create flexible manufacturing systems and highly efficient supply chains within which the time for each activity is cut to a minimum and the punctuality of all deliveries by each link in the chain becomes a strategic imperative.

On January 31, 2010, the Inditex group has a network of 1237 suppliers with which it maintains stable relations based on its External Manufacturers and Workshops Code of Conduct, which each partner must sign up to before the collaboration begins, and which binds him to respect both the times and the standards requested for each supply (Inditex Report 2009, p. 17).

Gap Inc. has about 3000 suppliers located in more than 50 countries, who sign up to its Code of Vendor Conduct. The decision to work with so many partners is explained by the need to distribute more effectively over a large number of suppliers the risks deriving from delivery delays, shipping problems, sudden increases in product demand, and non-conformity with set standards. (Gap Inc. Annual Report 2009)

H\&M has 15 manufacturing offices in Asia and Europe, which work in close contact with 700 suppliers. The latter undertake to respect the standards set by H\&M which carries out numerous inspections in its partners' plants to monitor the quality of the products and respect of 
codes of practice covering working conditions and environmental impact, as established by its social responsibility policies. (H\&M Annual Report 2009)

By emphasising activities downstream of the supply chain and relying on outsourced supplies, the companies opt to concentrate all their products from different suppliers in a small number of distribution centres. In these warehouses, the articles are positioned in two sectors, depending whether they are folded or hanging, and they are catalogued by model, colour and size so that they are easy to handle.

\subsection{Fast Fashion, ICT and Information Management}

Monitoring of the supply chain and the reduction of time to market are sustained by innovative IT processes that make it possible to follow the product in all its movements. Information and Communications Technology (ICT) is absolutely essential to manage the enormous quantity of data and information that circulates between the various company departments, as well as between partner companies.

ICT has generated a significant transformation in fast fashion companies, and not only with particular reference to the order management system, with orders now transmitted in real time, but also with a new manufacturing set-up that involves all company activities, from the design of each article through to its delivery to the point of sale. For example, to reduce processing times, it is likely that 'digital design' will soon be used extensively. Here the speed of production is determined by the rapid digitalisation of the image and the industrialisation of the drawing. Technology is also improving the efficiency of the central warehouses near the manufacturing plants, where wrapped clothes transit for a short time. Here automatic sorters divide the articles by type, model and colour and rapidly make up the orders of goods to be sent to the points of sale (Forza, Vinelli, 1997).

Particular innovations to the software in the stores make it easier to manage reassortments, and the articles can be delivered rapidly, already priced and ready for display. What is more, the introduction of RFID technology (Radio Frequency Identification) in the process to transport the product from the supplier's warehouse to the point of sale and its purchase by the consumer, has made it possible to monitor products better along the supply chain, also rationalising the order entry process (Garrido, Ferreira, 2009).

$\square$ According to recent data from the American Abi Research Institute, in the clothing industry, RFID is no longer a phenomenon linked to some pilot projects conducted by a limited number of firms on consistent movements. At all levels of the chain, the firms see RFID as an opportunity to manage the entire Supply Chain in the best possible way and, above all, to boost sales thanks to the optimisation of inventories and total visibility of stock in the warehouse. Analysts have estimated that in the next five years, sales of RFID systems in the textile sector will treble, reaching $\$ 125$ million by the end of $2014^{8}$. 
The main sources of information necessary to prepare the design and planning of fast fashion products are direct observation of reality and analysis of sales data. In reality there are numerous sources of inspiration: fashion magazines, fashion shows, competitors' publications, the style adopted by celebrities and opinion leaders, television series and places frequented by the young people, such as university campuses.

Where stylistic research is concerned, Zara does not invest huge resources in the study of new trends but responds to them very rapidly. It cannot therefore be defined as a first mover innovator but as a follower that imitates what other people have identified as emerging trends, efficiently and rapidly. For this reason, its team of designers observes the fashion shows of the large fashion houses and other fashion events, and monitors generator trends to grasp future orientations and to prepare the collection.

$\square H \& M$ on the other hand has for some years been collaborating with very well-known designers like Karl Lagerfeld, Stella McCartney, Viktor \& Rolf, Roberto Cavalli, Comme des Garçons, Mathew Williamson, Jimmy Choo and Sonia Rykiel.

$\square$ Gap has also decided to take this direction recently, collaborating with Stella McCartney on a collection of children's shoes.

Another primary source of information is the feedback about sales data. Every day, the results related to sales in the various stores are aggregated in a single database that the stylists can access to see which articles have sold most and, therefore, what is the prevalent trend in purchasing tastes, so as to address the design of future articles. Feedback about sales is also transmitted every day to the purchasing and production departments so that they can orient purchases and manufacturing. It is also verified twice a week, when products are re-ordered by the store managers who can identify trends better, because they come into direct contact with customers.

Decisions about which items of clothing or accessories to continue to produce and which to eliminate from the assortment because they are slow-moving, are therefore taken during the season in which the products are sold and not months earlier as in the traditional clothing sector.

\subsection{Fast Fashion, Stores Management and Customer Linking Capability}

The distribution and selling stage of the products provides information both to identify demand preferences and to organise re-order flows. The point of sale thus becomes a privileged location to generate market knowledge (Barnes, LeaGreenwood, 2010).

Table 1 lists the number of stores for each brand and the countries in which they are located. 
Table 1: H\&M, Inditex, Gap Inc. Global Distribution

\begin{tabular}{|c|c|c|c|c|}
\hline $\begin{array}{l}\text { Fast Fashion } \\
\text { Companies }\end{array}$ & $\begin{array}{c}\begin{array}{c}\text { Number } \\
\text { of }\end{array} \\
\text { countries } \\
\text { with } \\
\text { points of } \\
\text { sale } \\
\end{array}$ & $\begin{array}{c}\text { Overall } \\
\text { number of } \\
\text { points of sale } \\
\text { globally }\end{array}$ & $\begin{array}{c}\text { Points of sale } \\
\text { managed } \\
\text { directly by the } \\
\text { company }\end{array}$ & $\begin{array}{c}\text { Points of } \\
\text { sale } \\
\text { franchised }\end{array}$ \\
\hline H\&M & 35 & 1.988 & $1.952(98 \%)$ & (36) $2 \%$ \\
\hline $\begin{array}{l}\text { INDITEX } \\
\text { Zara } \\
\text { Pull and Bear } \\
\text { Massimo Dutti } \\
\text { Bershka } \\
\text { Stradivarius } \\
\text { Oysho } \\
\text { Zara Home } \\
\text { Uterque }\end{array}$ & 74 & $\begin{array}{c}4.607 \\
1.608 \\
626 \\
497 \\
651 \\
515 \\
392 \\
261 \\
57\end{array}$ & $\begin{array}{c}3.983(87 \%) \\
1.442(90 \%) \\
541(86 \%) \\
372(75 \%) \\
574(88 \%) \\
416(81 \%) \\
359(92 \%) \\
233(89 \%) \\
46(81 \%)\end{array}$ & $\begin{array}{c}624(13 \%) \\
166(10 \%) \\
85(14 \%) \\
125(25 \%) \\
77(12 \%) \\
99(19 \%) \\
33(8 \%) \\
28(11 \%) \\
11(19 \%)\end{array}$ \\
\hline $\begin{array}{l}\text { GAP Inc. } \\
\text { Gap } \\
\text { Banana } \\
\text { Republic } \\
\text { Old Navy }\end{array}$ & 28 & $\begin{array}{c}3.247 \\
1.537 \\
638 \\
1.036\end{array}$ & $\begin{array}{c}95 \% \\
1.437(91 \%) \\
609(95 \%) \\
1.036(100 \%)\end{array}$ & $\begin{array}{c}5 \% \\
136(9 \%) \\
29(5 \%) \\
0\end{array}$ \\
\hline
\end{tabular}

Source: Elaborated by the author using data for 2009 and $2010^{9}$

Table 1 reveals that for the companies considered, almost all the stores are managed directly, whereas only a small part, about $5-10 \%$, is franchised. This contract formula is usually the one chosen to enter countries with administrative barriers to entrance, like Saudi Arabia, Kuwait or the UAE. Very rarely, some fashion retailers have created joint ventures, as in the case of Zara and the Indian Tata Group, for which a collaboration agreement was established to meet strict Indian legal requirements ${ }^{10}$.

We can however state that, to develop good understanding of the commercial phenomena in the various countries, and to implement a reactive approach to the market, Zara, H\&M and Gap have opted for a direct sales network of single-brand stores disseminated all over the global territory ${ }^{11}$.

The choice of which country to open a new store in is an important strategic decision, taken after detailed research that analyses the macro and micro environment within which the company will operate. After a detailed study of local players, the company outlines a rapid growth plan, with numerous new stores opening in the vicinity of the first store. This might appear risky for the potential effect of cannibalisation between points of sale of the same store-brand but is, in fact, justified from the viewpoint of cost containment. The presence of several points of sale in a single town makes it possible both to define the brand identity in the consumer's mind better and to distribute transport, delivery and advertising costs on a broader base. 
Stores do not merely perform the function of distributing products, but represent the point of contact between the company and customers. As a result, the strategic decision of having a distribution structure that is almost entirely controlled allows fashion retailers to reach numerous objectives.

To start with, the location of the points of sale in the world's major markets links the global logics of corporate growth with the needs of individual local markets. Secondly, the economic risk deriving from working in a sector in which demand is heterogeneous and competition between companies is fierce can be managed better. What is more, controlling the marketing and sales network enables to gather all the information coming from contact with demand without filters and in real time. This way, we have immediate feedback about sales and the success of the policies adopted in order to orient the formulation of strategic future actions.

Another important function performed by single-brand points of sale is to spread the brand identity. The store is the main channel of communication of fast fashion companies which manage to attract and retain the clientele on the premises by defining its location and interior layout and the atmosphere of the services provided. The development strategy of Zara, Gap and H\&M often envisages the opening of flagship stores in major cities. The goal of this distribution format is to spread the brand values, creating an environment in which the customer can spend time pleasantly and also increases the probability that he will make a purchase, by increasing the length of his stay in the point of sale.

The locations chosen for the stores are in numerous areas of large cities: these certainly include the busiest inner city streets, like Corso Vittorio Emanuele in Milan or the Champs Elysées in Paris. But the choice of the fast fashion firms is not limited to these, in fact the stores are located in any point of the city that can guarantee a large catchment area of users and plenty of transit. For example, shopping malls or railway stations. Customers visit the former as a form of entertainment in their free time, and there are also numerous stores belonging to competitors, so that the presence of one of the chain's stores becomes a competitive necessity. Stations, on the other hand, are places where numerous people hang around while they wait to depart and therefore a store where they can do some shopping to fill their time, is certainly an appealing idea.

Even the internal layout of the shops is managed in every detail and considers both the positioning of the equipment (tills, display units, counters) and that of the products (usually divided by commodity class). In fashion retailers' stores, the traditional breakdown of the display space into departments is often replaced by large open spaces where the items are already matched with accessories or cosmetics. This is evident at Gap, where typical American jeans are placed closed to shoes to wear with them, or at H\&M which locates ranges of bath foam and body creams near to underwear collections, thus stimulating joint purchases by customers.

Zara considers the layout of the shops and the window dressing so important that they are decided in the head office in Arteixo, where the spaces are recreated to study the lighting and to identify the best route for customers to follow. The best layouts identified are photographed and sent by email to the stores so that they can be recreated as shown.

All these actions are taken in order to relate positively with the clientele. Marketoriented companies include among their distinctive capabilities the ability to 
manage relations with end customer. These 'customer linking' capabilities are qualified by their breadth and depth, in other words the number of relations activated and the intensity of each one (Day, 2003). Zara, H\&M and Gap have stores all over the world which enables them to collect endless information about the peculiar characteristics of customers in different countries.

Fast fashion firms do not limit themselves to studying demand, but use the information collected to influence behaviour. For example, in recent years, consumers have tried to develop an original style, perhaps by combining an item of 'standard-mass market' clothing, which everyone has, with a particular accessory like a scarf or an exclusive belt. This combination between products from different price brackets or commodity classes has actually been induced by fashion retailers themselves, who do not only distribute items of clothing, like frocks, jackets, skirts, etc., in their points of sale, but also footwear, perfume, cosmetics, spectacles and bags. What is more, we can see that the behaviour of demand for items of clothing and accessories varies widely and is linked to the concept of dispersion, in other words the consumer distributes his purchases in numerous locations and distribution formats; from the boutique to the outlet and the market stall. This is explained primarily by the limited spending power of potential purchasers and also by the desire for a personal style. If the available budget is limited, the quality-price ratio becomes the deciding variable. This explains the recent success of numerous real (Serravalle Scrivia or Fox Town) and virtual outlets (the portals www.yoox.com or www.bluefly.com, where clients can find clothing and accessory from the past collections of big designers, at prices significantly below recommended prices).

Fast fashion companies have also encouraged changes in the timing of purchases. Whereas in the past we would buy the articles typical of a given period at the start of that period, i.e. a Winter coat would be purchased in November-December, today company strategies have intensified the launch of spot collections in periods well in advance of seasonal requirements, thus driving consumers to purchase products independently of seasonal needs. What is more, the continuous refreshing of supply with new collections that only go on display for a few days and, what is more, are also rotated inside the point of sale in that time, imparts a sense of urgency to purchase to customers. As a result of the frequent re-assortment and rotation of articles inside the store, fashion retailers have generated a 'scarcity effect' (marketbubble management) that prompts consumers to impulse buy: a customer who goes to Zara, Gap or H\&M and sees an item that he likes, knows that he must buy it immediately or risk not finding it again.

The assiduous launch of new collections obliges customers to go to the point of sale more frequently to check on the new proposals and purchase them if they are of interest. This mechanism increases traffic in the store and multiplies selling opportunities, but it also creates very small stocks of items and Zara, H\&M and Gap sales only last a few days because the unsold items disappear rapidly.

A recent innovation introduced in relation to demand is the creation of the direct marketing channel. First of all H\&M (in Sweden, Norway, Denmark, Finland, Germany, Austria and the United Kingdom) and Gap (primarily in North America and Europe), followed by Zara in September 2010 (in Spain, France, Germany, the United Kingdom, Italy and Portugal), have all launched online stores. 
This decision has numerous strategic repercussions for fast fashion companies: first of all, it further reduces time to market, because it postpones the delivery of the items until after the sale is concluded and as a consequence, makes it possible to reach the market first. Secondly, it eliminates the costs linked to the creation and management of physical stores; we only have to remember that expenses for rents and employee remuneration are among the largest items in company accounts. And finally, online marketing channels reach a larger number of customers, whose data may be profiled, thus making it easier for designer teams to identity the latest demand preferences and trends, by analysing purchasing behaviour, which can be tracked in real time.

From the viewpoint of the customer who has already bought items from that specific clothing chain and is familiar with its sizes and processes, online purchasing avoids useless queues in the store and gives the illusion of being able to find everything that the collections offer (in terms of sizes and colours). But virtually too, the creation of continuous spot offers combined with efficient timebased management tends to generate a scarcity effect.

\section{Conclusions and Emerging Issues}

In major theoretical studies of Market-Driven Management, the management of information has been considered by many scholars as a central element; however, if the information collected and processed is to provide a platform for the creation of new knowledge, the company must also have a learning orientation. What is more, studies undertaken reveal that learning from the market and knowledge are closely linked to a company's capability to innovate.

The research focused on studying innovation in market-driven companies that operate in a global context and are strongly competitive. In this situation, to grow in the long term, a company oriented to competitor and demand must know how to manage a wealth of information, have detailed understanding of the market and must develop the ability to learn from the latter, it must also have developed an 'innovation management capability'.

We have examined the fast fashion sector by studying the cases of Zara, H\&M and Gap, to show that, through tight control of the distribution network, these companies manage to develop profound knowledge of the dynamics of the global markets and to implement successful strategic innovations. An understanding of global trends allows Zara, Gap and H\&M to monitor the complexity and instability of today's markets, arriving before (sooner) and better (with offers whose values is perceived to be higher for the customer) than their competitors.

The companies selected have succeeded in introducing numerous innovations into their everyday corporate management: in the Supply Chain (focusing constantly on time management and the consequent reduction in the time needed for each corporate activity); in Information and Communications Technology (with innovative IT processes that can follow the product in all it movements, thanks to Digital Design, automatic Sorters and RFID systems); and in relations with demand (where they have developed customer linking capabilities, proposing a very differentiated assortment that reflects the trends of the moment). 
The key aspect that emerges from the research is that approximately $95 \%$ of the Zara, Gap and H\&M stores are managed directly; this control over the worldwide distribution and sales structure profoundly impacts on the generation of knowledge about the market and, as a consequence, on the ability to develop innovation management capabilities. Through direct contact with demand and the far-flung dissemination of their stores in the major countries of the world, these companies have succeeded in facing up to the instability of the global markets and even in transforming it into an element of success for themselves by the continuous creation and abandon of demand vacuums.

\section{Bibliography}

Abell Derek F., Strategic Windows, Journal of Marketing, vol. 42, n. 3, 1978, pp. 21-28. http://dx.doi.org/10.2307/1250529

Baker William E., Sinkula James M., The Complementary Effects of Market Orientation and Entrepreneurial Orientation on Profitability in Small Businesses, Journal of Small Business Management, vol. 47, n. 4, 2009, pp. 443-464. http://dx.doi.org/10.1111/j.1540-627X.2009.00278.x

Baker William E., Sinkula James M., Market Orientation, Learning Orientation and Product Innovation: Delving into the Organization's Black Box, Journal of Market-Focused Management, vol. 5, n. 1, 2002, pp. 5-23. http://dx.doi.org/10.1023/A:1012543911149

Baker William E., Sinkula James M., Learning Orientation, Market Orientation, and Innovation: Integrating and Extending Models of Organizational Performance, Journal of Market-Focused Management, vol. 4, n. 4, 1999, pp. 295-308. http://dx.doi.org/10.1023/A:1009830402395

Barnes Liz, Lea-Greenwood Gaynor, Fast fashion in the Retail Store Environment, International Journal of Retail \& Distribution Management, vol. 38, n. 10, 2010, pp. 760-772. http://dx.doi.org/10.1108/09590551011076533

Brondoni Silvio M., Market-Driven Management, Competitive Customer Value and Global Network, Symphonya. Emerging Issues in Management (symphonya.unimib.it), n. 1, 2009. http://dx.doi.org/10.4468/2009.1.02brondoni

Brondoni Silvio M., Market-Driven Management, Competitive Space and Global Network, Symphonya. Emerging Issues in Management (symphonya.unimib.it), n. 1, 2008. http://dx.doi.org/10.4468/2008.1.02brondoni

Christensen Clayton, The Innovator's Dilemma, Harvard Business School Press, Cambridge, 1997.

Cillo Paola, Verona Gianmario, Search Styles in Styles Searching: Exploring Innovation Strategies in Fashion Firms, Long Range Planning, vol. 8, n. 1, 2008, pp. 1-22. http://dx.doi.org/10.1016/j.lrp.2008.08.001

D'Aveni Richard, Hyper-competition. Managing the Dynamics of Strategic Manoeuvring, Free Press, New York, 1994.

Day George S., Creating a Superior Customer-Relating Capability, Mit Sloan Management Review, vol. 44, n. 3, 2003, pp. 77-82.

Day George S., The Capabilities of Market-Driven Organizations, Journal of Marketing, vol. 58, $\mathrm{n}$. 4, 1994, pp. 37-52. http://dx.doi.org/10.2307/1251915 
Dupuis Marc, Innovation dans la distribution. Le paradoxes de la prospective, Revue Française du Marketing, n. 188, 2002, pp. 61-68.

Dutta Devangshu, Retail@ the Speed of Fashion, The Third Eyesight, 2003.

Forza Cipriano, Vinelli Andrea, Quick Response in the Textile-Apparel Industry and the Support of Information Technologies, Integrated Manufacturing System, vol. 8, n. 3, 1997, p. 125.

http://dx.doi.org/10.1108/09576069710181947

Gap Inc. Annual Report 2009.

Garrido Azevedo Susana, Ferreira Joao, RFID Technology in Retailing: an Explanatory Study on Fashion Apparels, Journal of Managerial Economics, vol. 7, n. 1, 2009, pp. 7-23.

Gummesson Evert, Qualitative Methods in Management Research, Sage, Thousand Oaks, 2000.

H\&M Annual Report 2009.

Hamel Gary, Strategy as Revolution, Harvard Business Review, vol. 74, n. 4, 1996, pp. 69-82.

Inditex Annual Report 2009.

Jaworski Bernard J., Kohli K. Ajay, Sahay Arvin, Market-Driven versus Driving Markets, Journal of the Academy of Marketing Science, vol. 28, n. 1, 2000, pp. 45-54.

http://dx.doi.org/10.1177/0092070300281005

Kohli Ajay K., Jaworski Bernard J., Market Orientation: The Construct, Research Propositions, and Managerial Implications, Journal of Marketing, April, pp. 1-18, 1990.

http://dx.doi.org/10.2307/1251866

Lugli Giampiero, Marketing Channel, Utet, Torino, 2007.

Mazaira Andres, Gonzales E., Avedano Ruth, The Role of Market Orientation on Company Performance through the Development of Sustainable Competitive Advantage: the Inditex/Zara Case, Marketing Intelligence \& Planning, vol. 21, n. 4/5, 2003, pp. 220-229.

http://dx.doi.org/10.1108/02634500310480103

Mihm Barbara, Fast Fashion in a Flat World: Global Sourcing Strategies, The International Business \& Economics Research Journal, vol. 9, n. 6, 2010, pp. 55-63.

Narver John C., Slater Stanley F., The Effect of a Market Orientation on Business Profitability, Journal of Marketing, October, 1990, pp. 20-35.

http://dx.doi.org/10.2307/1251757

Narver John C., Slater Stanley F, MacLachlan Douglas L., Responsive and Proactive Market Orientation and New Product Success, The Journal of Product Innovation Management, vol. 21, n. 5, 2004, pp. 334-347.

http://dx.doi.org/10.1111/j.0737-6782.2004.00086.x

Prahalad C.K., Hamel Gary, The Core Competence of the Corporation, Harvard Business Review, May-June, 1990, pp. 79-92.

Schumpeter Joseph, Capitalism, Socialism and Democracy, London, Unwin University Books, 1952.

Sciarelli Mauro, Resource-based Theory and Market-Driven Management, Symphonya. Emerging Issues in Management (symphonya.unimib.it), n. 2, 2008. http://dx.doi.org/10.4468/2008.2.06sciarelli

Sullivan Pauline, Kang Jikyeong, Quick Response Adoption in the Apparel Manufacturing Industry: Competitive Advantage of Innovation', Journal of Small Business Management, vol. 37, n. 1, 1999, pp. 1-13.

Teece David J., Pisano Gary, Shuen Amy, Dynamic Capabilities and Strategic Management, Strategic Management Journal, vol. 18, n. 7, 1997, pp. 509-533.

http://dx.doi.org/10.1002/(SICI)1097-0266(199708)18:7<509::AID-SMJ882>3.0.CO;2-Z 
Tokatli Nebahat, Global Sourcing: Insights from the Global Clothing Industry - the Case of Zara, a Fast Fashion Retailer, Journal of Economic Geography, vol. 8, n. 1, 2008, pp. 21-38.

Tuominen Matti, Rajala Arto, Möller Kristian, Market-Driving Versus Market-Driven: Divergent Roles of Market Orientation Business Relationships, Industrial Marketing Management, vol. 33, n. 3, pp. 207-217, 2004.

http://dx.doi.org/10.1016/j.indmarman.2003.10.010

Vitzthum Carlta, Just-in-Time Fashion. Spanish Retailer Zara Makes Low-Cost Lines in Weeks By Running Its Own Show, Wall Street Journal (Eastern Edition), New York, May 18, 2001, p. B1.

Yin Robert, Case study Research. Design and Methods, Third Edition, Sage, Thousand Oaks, 2003.

Zucchella Antonella, Essays on the Economics and Management of Innovation, IUSS Press, Pavia, 2004.

\section{Notes}

${ }^{1}$ Joseph Schumpeter (1883-1950) was the first scholar to talk about innovation, stating that the technological competition to be reached by innovation was at the centre of economic change. For more details we refer you to J. Schumpeter, Capitalism, Socialism and Democracy, London, Unwin University Books, 1952.

${ }^{2}$ It is possible to identify two approaches to the study of innovation in managerial economics: one is tangible (also described as 'technology-driven') and the other is intangible. In the former the technological-material aspect prevails and the source of innovation is a new discovery or invention that often aims to improve the effectiveness and efficiency of the manufacturing process. This view derives from Schumpeter's theory based on the invention-innovation-diffusion cycle. The latter, on the other hand, embodies an intangible view of innovation that regards the strategic action of the company in the wider sense of the term. In other words, the innovative change does not refer only to an individual product or process but also to new organisational models or company activities. See: A. Zucchella, Essays on the Economics and Management of Innovation, IUSS Press, Pavia, 2004.

${ }^{3}$ Christensen (1997), in this regard, distinguishes between: 'sustaining' innovations (that bring benefits and incremental improvements for the customer) and 'disruptive' innovations (which are new value propositions). See: C. Christensen, The Innovator's Dilemma, Harvard Business School Press, Cambridge, 1997

4 Jaworski, Kohli and Sahay (2000) and Tuominem, Rajala and Möller (2004) define this management philosophy as a 'market driving approach'. See: Jaworski Bernard J., Kohli K. Ajay, Sahay Arvin, Market-Driven versus Driving Markets, in Journal of the Academy of Marketing Science, Vol. 28, n. 1, 2000, pp. 45-54; Tuominen Matti, Rajala Arto, Mo“ller Kristian, Marketdriving versus Market-Driven: Divergent Roles of Market Orientation Business Relationships, in Industrial Marketing Management, Vol. 33, n. 3, pp. 207-217, 2004.

${ }^{5}$ The case study is one of the methods used to carry out investigations in social sciences; it is better to use it to investigate why a phenomenon occurs and how it develops. The case study is recommended to examine events contemporary to the investigator and it draws on secondary data, on the direct observation of the phenomenon and on interviews with people involved. The major limitations of its use are the fact that the results are not generalised and that it does not adopt systematic procedures. Cf. R. Yin, Case study research. Design and methods, Third Edition, Sage, Thousand Oaks, 2003; E. Gummesson, Qualitative Methods in Management Research, Sage, Thousand Oaks, 2000.

${ }^{6}$ In the clothing sector, Lugli identifies the following distribution formats: independent multibrand stores, department stores, large specialist areas, chains of single-brand stores, flagship stores, factory outlets, planned superstores and shopping malls, and digital distribution channels. 'Chains 
have grown up in the world clothing market with exclusive brands-stores that address a precise customer target. Benetton, Gap, Zara, H\&M, Esprit, Max Mara and Promod propose a unique assortment that corresponds to the store brand. Some, like Max Mara and Benetton, are producers integrated downstream; others, like Gap, H\&M and Zara, are distributors integrated upstream. The focus on a small target is an incentive to international development.' See: G. Lugli, Marketing Channel. Utet, Turin, 2007, p. 380.

${ }^{7}$ For a detailed examination of innovation in retailing, we refer you, among others, to: Marc Dupuis, Innovation dans la distribution. Le paradoxes de la prospective, in Revue Française du Marketing, n. 188, 2002, pp. 61-68.

${ }^{8} \mathrm{Cf}$. http://rfid.thebizloft.com.

${ }^{9}$ The information necessary to describe the companies selected and to elaborate Table 1 is taken from the 2009 Annual Reports and documents downloaded from the companies' websites: (http://www.hm.com), (www.inditex.com), (www.gap.com). The data for H\&M are updated to $30 / 11 / 2009$, those of Inditex to 31/01/2010, and those for Gap Inc. to 30/10/2010.

${ }^{10}$ The joint venture was created by Zara, which holds 51\%, and Trent (49\%), a company in the Tata Group. Cf. (www.tata.com), Joint venture company to be formed, February 5, 2009.

${ }^{11}$ Benetton was a precursor of many of the strategies adopted by fast fashion companies. In the ' $70 \mathrm{~s}$ and ' $80 \mathrm{~s}$, initially in a local context, it succeeded in creating products very rapidly and in implementing innovations which, even subsequently, were adopted widely, such as the decision to dye articles only after receiving feedback about sales results. In the ' $80 \mathrm{~s}$ it embarked on an internationalisation programme that now means that Benetton owns 6,300 stores in 120 countries. However, clothing is no longer the company's core activity. It is now a part of the Edizione S.r.l. holding company, which operates in numerous sectors: retail (with the Benetton and Autogrill brands), infrastructure and mobility services (with Autostrade), insurance, real estate, agriculture, etc. (Cf. www.benettongroup.com). 